BMJ Paediatrics Open

\section{Where do we go from here? A child rights-based response to COVID-19}

To cite: Raman S, Harries M, Nathawad R, et al. Where do we go from here? A child rightsbased response to COVID-19. BMJ Paediatrics Open 2020;4:e000714. doi:10.1136/ bmjpo-2020-000714

Received 13 May 2020 Revised 26 May 2020 Accepted 27 May 2020
Check for updates

(c) Author(s) (or their employer(s)) 2020. Re-use permitted under CC BY-NC. No commercial re-use. See rights and permissions. Published by BMJ.

For numbered affiliations see end of article.

Correspondence to Dr Shanti Raman; shanti. raman@health.nsw.gov.au
The global COVID-19 pandemic is already this century's largest, expanding exponentially with millions of confirmed cases. While this virus impacts relatively few children through severe morbidity or mortality, they nonetheless experience heightened adversity as governments around the globe intervene with drastic social control measures. Over 1.5 billion children were out of school at the current peak, and widespread job losses and economic insecurity are likely to increase rates of children's exploitation, labour, maltreatment and teenage pregnancy. ${ }^{2}$

Recommendations for children's health and healthcare during COVID-19 have been developed. ${ }^{3}$ Many regional, national and global agencies have advocated for measures to mitigate potential harms to children associated with pandemic prevention interventions. ${ }^{45}$ Public health measures to implement social distancing and limit the virus's spread must be balanced with measures that protect and promote the rights of all children across the globe. We outline the children and young people (CYP) most at risk globally and call for a rights-based agenda for action to alleviate potential and real harms to children, acknowledging that the long-term impacts of the COVID-19 response, especially the economic downturn, are likely to increase inequities on a national and international basis.

\section{WHO IS MOST AT RISK?}

This pandemic's scale notwithstanding, given the estimates of CYP exposed to some form of neglect and violence, the magnitude of vulnerable CYP globally could be well over one billion. ${ }^{6}$ Research shows us that the social determinants of health are clustered. The CYP within these clusters and in need of enhanced attention include the following.

- Socially/economically disadvantaged CYP and families-children living in poverty, particularly street and working children, those living in poor and overcrowded housing.

- Aboriginal/First Nations/indigenous CYP.

- Refugee, migrant and displaced CYP and those affected by conflict.

- CYP at risk of violence and exploitation including those not yet in the protective system.

- Orphaned and abandoned CYP and those socially isolated.

- CYP with a disability, or long-term health conditions; with behavioural/mental health difficulties.

- CYP in residential care, alternative care, detention and in conflict with the law.

- CYP impacted by gender discrimination, including specific discrimination against the girl child.

\section{WHAT ARE THE DIRECT AND INDIRECT HEALTH AND SOCIAL CONSEQUENCES FOR CYP?}

While children generally have less severe clinical manifestations from COVID-19 than adults, certain groups are more vulnerable including young children, and those with respiratory conditions, immunodeficiency, neurodevelopmental disability and obesity. ${ }^{3}$ Immediate public health responses are required to keep CYP safe during the pandemic, while maintaining vigilance on those with disability and chronic health conditions who may be more at risk of severe 


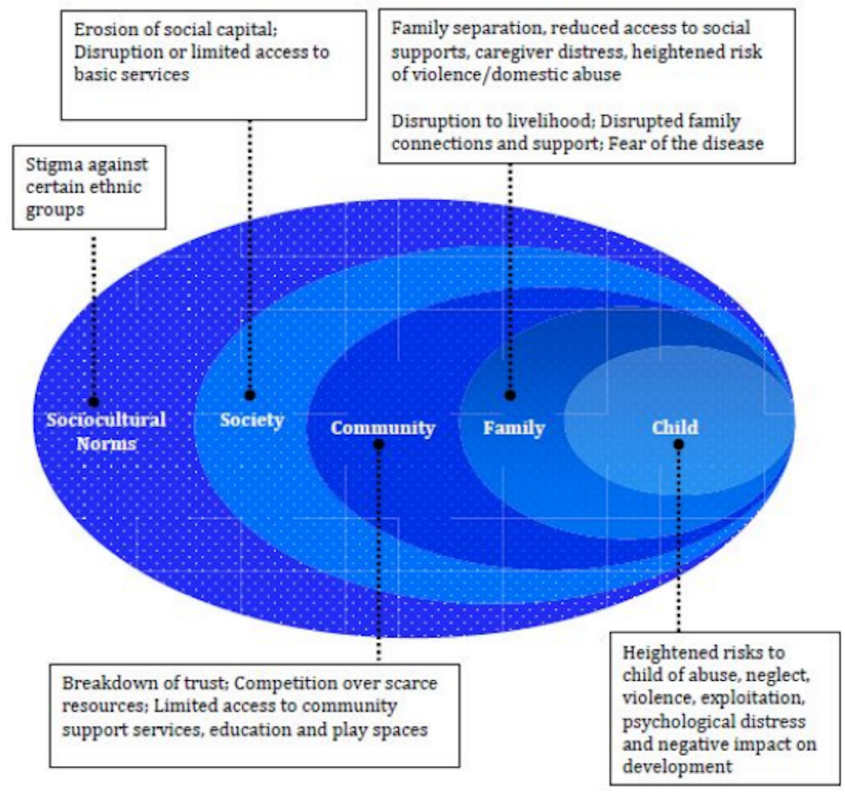

Figure 1 Socio-ecological impact of COVID-19. Adapted from The Alliance for Child Protection in Humanitarian Action. $^{8}$

morbidity and even mortality. Underlying health inequities are pronounced during this pandemic.

The irony is public health measures aimed at preventing one disease can exclude and undo preventive efforts to intervene proactively in the lives of many vulnerable CYP globally. The indirect impacts and unintended consequences of pandemic responses are potentially most damaging. These include delayed acute presentations, foregone treatment for chronic health conditions and increased burden of mental health conditions. The consequences of death of a parent or carer from the disease can be devastating.

Public measures that severely restrict movement and threaten livelihoods, especially in low resource settings where most people work in informal sectors, impact severely on CYP. Thousands of children are being tipped into starvation. Physical and social distancing increase stressors within already fragile families, with potential for increased violence and child maltreatment, sedentary behaviours and screen time.

Many thousands of CYP with disabilities have had their interventions suspended; immunisation programmes have been threatened; CYP with chronic health conditions denied routine or preventive health services including screening; access to sexual and reproductive services are being compromised; and, many children at risk of serious maltreatment are no longer in our gaze due to reduced safety nets. While school and early childhood service closures can cause immeasurable damage to children's well-being, education policies focused on online learning in the wake of COVID-19 have highlighted longstanding inequities with delays in learning most profound for the most deprived; the right to education and play are rights exclusive to children.
Table 1 Articles of the United Nations CRC that relate to healthcare work

\begin{tabular}{|c|c|}
\hline Article & Purpose \\
\hline Article 2 & Protection from discrimination \\
\hline Article 3 & $\begin{array}{l}\text { Best interests of the child a primary } \\
\text { consideration; the institutions, services and } \\
\text { facilities responsible for the care or protection } \\
\text { of children shall conform with the standards } \\
\text { established by competent authorities }\end{array}$ \\
\hline Article 5 & $\begin{array}{l}\text { Parents responsible for ensuring that child's } \\
\text { rights are protected }\end{array}$ \\
\hline Article 6 & Right to survival and development \\
\hline Article 9 & $\begin{array}{l}\text { Right of the child who is separated from one or } \\
\text { both parents to maintain personal relations and } \\
\text { direct contact with both parents on a regular } \\
\text { basis }\end{array}$ \\
\hline Article 12 & $\begin{array}{l}\text { The right of a child to express their view: with } \\
\text { weight given according to the maturity of the } \\
\text { child }\end{array}$ \\
\hline Article 13 & $\begin{array}{l}\text { Freedom of expression including seeking, } \\
\text { receiving and imparting information }\end{array}$ \\
\hline Article 16 & Protection of privacy \\
\hline Article 17 & $\begin{array}{l}\text { Access to information from mass media, with } \\
\text { protection from material injurious to his or her } \\
\text { well-being }\end{array}$ \\
\hline Article 18 & $\begin{array}{l}\text { Assistance to parents with child rearing } \\
\text { responsibilities }\end{array}$ \\
\hline Article 19 & $\begin{array}{l}\text { Protection from physical or mental violence, } \\
\text { abuse, or neglect }\end{array}$ \\
\hline Article 20 & $\begin{array}{l}\text { Special protection for children deprived of their } \\
\text { families }\end{array}$ \\
\hline Article 22 & Protection of children seeking refugee status \\
\hline Article 23 & Rights of disabled children to special care \\
\hline Article 24 & Right to health and access to healthcare \\
\hline Article 27 & Right to an adequate standard of living \\
\hline Article 28 & Right to education \\
\hline Article 30 & Right to own culture and religion \\
\hline Article 31 & Participation in leisure and play \\
\hline Article 34 & Protection from sexual exploitation \\
\hline
\end{tabular}

Source: Adapted from Waterston. ${ }^{7}$

CRC, Convention on the Rights of the Child.

Welfare, social and family support services critical for vulnerable CYP may be suspended or provide only remote access. CYP may be further disadvantaged during the postpandemic recovery phase, with widening income inequalities and amplification of the digital divide, severely affecting family access to basic nutrition, shelter, information and education. Figure 1 illustrates how COVID-19 can drastically alter a child's environment and negatively impact their well-being.

\section{WHAT ARE WE CALLING FOR?}

Child rights-based responses afford us opportunities to advance policies and practices to mitigate the direct and 
Keep children and young people (CYP) visible and participating during this pandemic; encourage, privilege and listen to $2,3,12$ their voices and their representatives.

Ensure universal access to quality maternal, newborn, child and adolescent healthcare and maintain preventive health measures including immunisation to keep CYP healthy, while also responding to meet the needs posed by COVID- 19 .

\section{Support CYP by proactively and assertively aiding and assisting their families and communities.}

3,24

Use the wisdom and intelligence of frontline workers, community leaders and organisations across diverse regions and

$3,6,9,18$

localities to understand and reach families and enable them to care for their children.

Recognise the fragility of CYP who have been either removed from their families, who have been orphaned or who are in $19,20,21,34$ various forms of care or detention by listening and responding with additional supports.

Identify and reach vulnerable children in communities where their health is already compromised by inadequate or no

housing, deficient sanitation and poor hygiene.

Enhance the focus on and support for, indigenous children, refugee and migrant children, those with a disability, those 2, 22, 23, 34 with chronic health conditions.

Mitigate the threat of compromised safety nets during the pandemic response by ensuring CYP continue to be protected $3,18,20$ within their families and communities.

Respond to the additional threats and risks of violence, exploitation and abuse to children from perpetrators capitalising $19,28,34$ on reduced school attendance and surveillance by authorities.

Keep CYP learning, expand internet access for families and children, and provide the support and technological capacity 3,28

to do so.

CRC, Convention on the Rights of the Child.

indirect threats of the COVID-19 pandemic. Fulfilling children's rights, as explicated in the United Nations Convention on the Rights of the Child (CRC-see table 1$),{ }^{7}$ and framed by the Sustainable Development Goals, establishes the prerequisites for achieving optimal health and well-being (health equity) and addressing health disparities (social justice). The right to health is related to and dependent on the realisation of other rights. Building on global agencies' advocacy, ${ }^{13-5}$ we recommend concerted national, regional and global efforts to respond to the following priorities for CYP (see table 2).

We need to privilege the rights of children, such that CYP are both seen and heard, responded to, protected from harms and health promoted, and provided opportunities to actively participate. ${ }^{1}$ We must refocus our gaze on the rights and needs of CYP, particularly those at risk. Proactive health and welfare are essential services-timely assessments and care, and interventions for ameliorating chronic conditions and disabilities must be maintained with continued delivery as safely as is possible. Of primary concern, are those groups affected by poverty, discrimination, or conflict, in which inequities are amplified both during the pandemic and recovery phase. Maintaining vigilance on those who are marginalised and stand to lose the most from this pandemic and in the post COVID-19 aftermath, is critical.

\section{Author affiliations}

${ }^{1}$ Department of Community Paediatrics, South Western Sydney Local Health District, Liverpool, New South Wales, Australia

${ }^{2}$ Women's \& Children's Health, University of New South Wales, Sydney, New South Wales, Australia

${ }^{3}$ Population and Public Health, The University of Western Australia Faculty of Health and Medical Sciences, Perth, Western Australia, Australia

${ }^{4}$ Pediatrics, University of Florida, Jacksonville, Florida, USA
${ }^{5}$ British Association of Child and Adolescent Public Health, Royal College of Paediatrics and Child Health, London, UK

${ }^{6}$ International Society for Prevention of Child Abuse \& Neglect (ISPCAN), New Delhi, India

${ }^{7}$ School of Health, University of New England, Armidale, New South Wales, Australia

Collaborators International Society for Social Pediatrics \& Child Health (ISSOP) COVID-19 Working Group: Karen Zwi; Nicholas J Spencer; Jeffery Goldhagen; Raul Mercer; Barbara Rubio; Giorgio Tamburlini; Sharon Goldfeld; Susan Woolfenden; Sarah Gander; Charles Oberg.

Contributors SR undertook planning, writing up and was responsible for the overall content; MH, RN, RK and RS provided content and writing of sections, BL provided content and editorial oversight.

Funding The authors have not declared a specific grant for this research from any funding agency in the public, commercial or not-for-profit sectors.

Competing interests None declared.

Patient and public involvement Patients and/or the public were not involved in the design, or conduct, or reporting, or dissemination plans of this research.

Patient consent for publication Not required.

Provenance and peer review Commissioned; externally peer reviewed.

Open access This is an open access article distributed in accordance with the Creative Commons Attribution Non Commercial (CC BY-NC 4.0) license, which permits others to distribute, remix, adapt, build upon this work non-commercially, and license their derivative works on different terms, provided the original work is properly cited, appropriate credit is given, any changes made indicated, and the use is non-commercial. See: http://creativecommons.org/licenses/by-nc/4.0/.

ORCID iD

Shanti Raman http://orcid.org/0000-0002-4546-3231

\section{REFERENCES}

1 Cuevas-Parra P, Stephano M. Children's voices in times of COVID-19: Continued child activism in the face of personal challenges. Uxbridge, United Kingdom: World Vision International, 2020.

2 UNICEF. Policy brief: the impact of COVID-19 on children. New York: United Nations Children's Fund, 2020.

3 Klein JD, Koletzko B, El-Shabrawi MH, et al. Promoting and supporting children's health and healthcare during COVID-19 - International Paediatric Association Position Statement. Arch Dis Child 2020:1-5. 
4 UNICEF. Protecting the most vulnerable children from the impact of coronavirus: an agenda for action. New York: United Nations Children's Fund, 2020.

5 Human Rights Watch. COVID-19 and Children's Rights. New York: Human Rights Watch, 2020.

6 Raman S, Muhammad T, Goldhagen J, et al. Ending violence against children: a call to action. Lancet Child Adolesc Health 2018;2:312-3.
7 Waterston T. A general paediatrician's practice in children's rights. Arch Dis Child 2005;90:178-81.

8 The Alliance for Child Protection in Humanitarian Action. Technical note: protection of children during the coronavirus pandemic. London: Save the Children, 2020. https://alliancecpha.org/en/system/tdf/ library/attachments/the_alliance_covid_19_brief_version_1.pdf?file= $1 \&$ type $=$ node\&id $=37184$ 